\section{HSE}

Historia Social y de la Educación

Social and Education History
Hipatia Press

www.hipatiapress.com

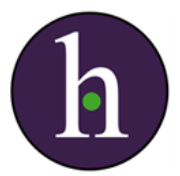

Instructions for authors, subscriptions and further details:

http://hse.hipatiapress.com

\title{
Slavery in a Remote but Global Place: the British East India Company and Bencoolen, 1685-1825
}

Richard B. Allen ${ }^{1}$

1) Editor of the Indian Ocean Studies Series, Ohio University Press

Date of publication: June $23^{\text {th }}, 2018$

Edition period: June 2018-October 2018

To cite this article: Allen, R.B. (2018). Slavery in a Remote but Global Place: the British East India Company and Bencoolen, 1685-1825. Social and Education History, 7(2), 151-176. doi:10.17583/hse.2018.3374

To link this article: http://dx.doi.org/10.17583/hse.2018.3374

\section{PLEASE SCROLL DOWN FOR ARTICLE}

The terms and conditions of use are related to the Open Journal System and to Creative Commons Attribution License (CC-BY). 


\section{Slavery in a Remote but Global Place: the British East India Company and Bencoolen, 1685- 1825}

Richard B. Allen

Editor of the Indian Ocean Studies Series, Ohio University Pres

\section{Abstract}

Histories of the British East India Company usually ignore the company's use of slave labor. Records from its factory at Bencoolen in Sumatra provide an opportunity to examine company attitudes and policies toward its chattel work force in greater detail. These sources reveal that the company drew slaves from a global catchment area to satisfy the demand for labor in its far-flung commercial empire, shed light on policies and practices regarding the treatment of company slaves, and illustrate the company's role in the development of increasingly interconnected free and forced labor trades during the late eighteenth and early nineteenth centuries. The Bencoolen case study also highlights the need to study colonial migrant labor systems in larger regional and global contexts.

Key words: Bencoolen, British East India Company, Indian Ocean, slave trading, slavery, Southeast Asia. 


\section{Esclavitud en un Lugar Remoto pero Global: la Compañía Británica de las Indias Orientales y Bencoolen, 1685-1825}

Richard B. Allen

Editor of the Indian Ocean Studies Series, Ohio University Press

\section{Resumen}

Las historias de la Compañía Británica de las Indias Orientales generalmente ignoran el uso de esclavos por parte de la compañía. Los registros de su fábrica en Bencoolen, Sumatra, brindan la oportunidad de examinar en mayor detalle las actitudes y políticas de la empresa hacia su fuerza de trabajo. Estas fuentes revelan que la compañía obtuvo esclavos de un área de captación global para satisfacer la demanda de mano de obra en su extenso imperio comercial, arrojan luz sobre las políticas y prácticas con respecto al tratamiento de esclavos de la compañía e ilustran el papel de la compañía en el desarrollo de un creciente número de intercambios de trabajo libre y forzoso cada vez más interconectados a finales del siglo XVIII y principios del XIX. El estudio de caso de Bencoolen también destaca la necesidad de estudiar los sistemas coloniales de migración laboral en contextos regionales y globales más amplios.

Palabras Clave: Bencoolen, Compañía Británica de las Indias Orientales, Océano Índico, tráfico de esclavos, esclavitud, Sudeste Asiático. 


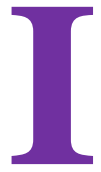

In July 1685, the Governor and Company of Merchants of London Trading into the East Indies, commonly known as the English East India Company (EIC) before 1708 and thereafter as the British East India Company, established a factory at Bencoolen (Benkulen, Bengkulu) on Sumatra's west coast as part of its plan to secure supplies of Sumatran pepper. The settlement, also known initially as York Fort and subsequently as Fort Marlborough, was not the first company establishment on the island. The EIC had already set up a factory further north along the coast at Priaman (Pariaman) which was expected to be the center of its pepper trade on the island, an expectation underscored by the issuance of orders in January 1685 for the Pryaman to sail to Madagascar to purchase slaves and carry them to Priaman where they were to be trained as craftsmen capable of building and repairing all kinds of ships. ${ }^{1}$ However, the existence of a Dutch East India Company (Vereenigde Oostindische Compagnie, or VOC) factory at Priaman and concern about Dutch plans to monopolize the pepper trade to India prompted the EIC's directors to decide in August 1687 to concentrate their Sumatran operations at Bencoolen. At the same time, they ordered 10 slaves on St. Helena, their colony in the South Atlantic, to be sent to York Fort to care for sick soldiers and possibly be used as armed guards. $^{2}$ The directors authorized officials on St. Helena to increase this number to 14 or 16 if they had any additional slaves to spare, but added that none of those to be sent to Bencoolen could come from among the 30 slaves that the island had received earlier from Madras, all of whom, the directors reported, were greatly prejudiced against Bencoolen because of the suffering they had endured during the course of an earlier voyage from Madras to Sumatra. ${ }^{3}$

This correspondence illustrates that the EIC not only made use of chattel labor, but also shipped slaves thousands of miles to satisfy the demand for such labor at its various establishments (Allen, 2014a, pp. 27-62). The widely scattered and often brief references to slaves in the company's archives (Geber, 1998, p. 101) make it difficult to determine the volume of this traffic with any precision. Available evidence suggests that the company acquired at least 10,000 and perhaps as many as 15,000 to 20,000 African, Indian, Malagasy, and Southeast Asian slaves between the 1620s and late 


\section{Allen - Slavery in a Remote but Global Place}

eighteenth century, mostly between the 1690s and early 1770s. These numbers pale in comparison to the hundreds of thousands of slaves traded by the Dutch, French, Portuguese, and others in the Indian Ocean during the seventeenth and eighteenth centuries, and the more than 2.97 million African slaves estimated to have been shipped across the Atlantic on British vessels during the same period. To assess the company's experience with chattel labor only in terms of the numbers of slaves it acquired, however, is to ignore the larger context within which this traffic occurred, including the need to view European slave trading between 1500 and the mid-nineteenth century as a truly global phenomenon rather than one confined largely to the Atlantic (Allen, 2014a, pp. 2, 19, 47).

Although a handful of scholars have explored aspects of the EIC's experience with chattel labor (Logan, 1956; Platt, 1969; Young, 1989; Harfield, 1995; Jayasuriya, 2009; Winterbottom, 2011; Fox, 2017), histories of the company (e.g., Bowen, 2006; Robins, 2006; Stern, 2009) rarely mention this activity because archival references to slavery at Bombay (Mumbai), Calcutta (Kolkata), and Madras (Chennai), the company's major centers in India, are scarce. However, the records of the "consultations" or managerial meetings at Bencoolen and the factory's correspondence with India and London between its establishment in 1685 and its transfer to the Dutch in 1825 provide an opportunity to examine the company's experience with slave labor in greater detail and situate this activity in more fully developed contexts. The Bencoolen case study is particularly important because it highlights that company policies and practices towards its slaves were shaped, at least in part, by humanitarian considerations, and illustrates the ways in which free and forced migrant labor systems in the European colonial world became increasingly intertwined during the late eighteenth and early nineteenth centuries (Allen, 2014a, p. 3).

\section{A Global Trade in Microcosm}

As elsewhere in the colonial world, the demand for slaves at Bencoolen was driven by a combination of economic, environmental, and other factors, the most salient of which was the unavailability and high cost of local free labor. As early as February 1686, officials at York Fort informed London of their "absolute need" for 50 or 60 slaves because local "Malay" laborers were 
expensive to hire, lazy, and difficult to control. Slaves, on the other hand, the fort's managers asserted, could be made to work at all hours and cost little or nothing to maintain since they could be employed in ways that ultimately allowed them to feed themselves. ${ }^{4}$

This belief in the cost-effectiveness of slave labor remained a regular refrain throughout much of the eighteenth century. In February 1704, Richard Watts and his colleagues supported their request for an additional 200 slaves on the grounds that such laborers could do twice the work of Malay "coolies" and cost no more than $\$ 14$ a year each to maintain. ${ }^{5}$ Factory officials made similar assertions in 1719 and $1758 .{ }^{6}$ Following its brief occupation by the French in 1760 during the Seven Years' War, officials at a resettled Fort Marlborough likewise justified a request to increase their slave population to 1,000 or 1,200 on the grounds that it cost much less to maintain slaves than to hire local Malays, an argument they repeated two and a half years later. ${ }^{7}$ The further passage of time did little to alter such observations. ${ }^{8}$

Environmental factors also played a role in shaping the local demand for chattel labor. Bencoolen quickly developed a reputation for being unhealthy, and frequent references to the death or infirmity of company employees attest to the impact that disease had on the settlement's inhabitants. ${ }^{9}$ Data on slave morbidity and mortality rates are limited, but scattered reports suggest that the factory's slaves suffered no less than its European residents. In 1705, for example, the settlement's hospital was unable to accommodate all of the slaves suffering from diarrhea. ${ }^{10}$ In 1722, the fort's doctor reported that the hospital housed an "abundance" of sick slaves whose recovery was being compromised by the poor quality of their rations. ${ }^{11}$ Forty years later, 65 of the factory's 354 slaves were reported to be sick in hospital. ${ }^{12}$

Epidemic disease, especially smallpox, posed a particularly serious threat. A smallpox epidemic in 1704 killed a majority of the factory's slaves. ${ }^{13}$ The death of a large number of slaves, including many of the settlement's most skilled workmen, from smallpox in 1748 prompted the company's directors to order the Swallow to Madagascar to purchase 250 slaves to replace those who had died. ${ }^{14}$ In July 1776 , local officials reported a "considerable" reduction in the number of slaves due to an unnamed illness. ${ }^{15}$ Eleven years later, despite precautions to prevent the disease from spreading, another serious outbreak of smallpox prompted local officials to 


\section{Allen - Slavery in a Remote but Global Place}

authorize the fort's surgeon to vaccinate the families and servants of the fort's European residents. ${ }^{16}$

The company drew slaves from a global catchment area to satisfy this demand for chattel labor. Slave censuses and other sources record the presence of "Coffrees" from eastern Africa and Madagascar, "Malabars" from southern India, and "Malays" from Southeast Asia, as well as men, women, and children identified specifically as coming from Angola, Bali, Bengal, Java, Madagascar, Mozambique, Nias, and Siam. However, as available data on slave ethnicity indicate (Table 1), company personnel preferred Malagasy slaves, a partiality that reflected well-developed beliefs about the purported attributes of the African and Asian peoples with whom they dealt. Malays were almost invariably regarded as lazy and untrustworthy, if not treacherous, while Indians supposedly lacked physical strength and stamina. Malagasies, on the other hand, had a reputation for being more intelligent and harder working than their Asian counterparts. In 1684, the company's directors observed that Malagasy slaves on Barbados were the "most ingenious" of that island's blacks in learning trades such as blacksmithing, bricklaying, carpentry, cooperage, and masonry, ${ }^{17}$ a belief that undoubtedly underpinned their 1685 instructions that the Malagasies ordered for Priaman should be trained as craftsmen and artisans. Bencoolen received similar instructions no later than $1713,{ }^{18}$ and continued to do so as the century progressed. ${ }^{19}$ As a result, local officials occasionally dispatched small numbers of young Coffree or Malagasy slaves to Madras to be trained as armorers, blacksmiths, bookbinders, bricklayers, and carpenters, as well as training such craftsmen locally. ${ }^{20}$ Early eighteenth-century assertions that one Malagasy slave was worth two or three from India, three or four from Nias, and three Malays, and that six good Coffrees were capable of doing the work of 20 Asian coolies echoed into the 1760s. ${ }^{21}$ Company-sponsored slaving voyages reflected this preference; Madagascar supplied the cargoes for 48 of the 75 known or authorized/probable company slaving voyages between 1622 and $1772 .{ }^{22}$ 
Table 1

Slave ethnicity at Bencoolen and dependencies, 1713-1781

\begin{tabular}{|c|c|c|c|c|c|c|c|}
\hline $\begin{array}{l}\text { Ethnicity/Place of } \\
\text { Origin }\end{array}$ & $\underline{1713}$ & $\underline{1730}^{\mathrm{a}}$ & $\underline{1742}$ & ${\underline{1748^{\mathrm{a}}}}$ & $\underline{1755}$ & $\underline{1766}$ & $\underline{1781}$ \\
\hline Angola & --- & --- & --- & --- & --- & 140 & 49 \\
\hline Bencoolen $^{\mathrm{b}}$ & --- & --- & --- & --- & --- & --- & 221 \\
\hline Coffree & 64 & --- & --- & --- & 67 & --- & --- \\
\hline Malabar & 60 & 12 & 18 & 12 & --- & --- & 12 \\
\hline Malagasy & --- & 108 & 226 & 134 & 245 & 491 & 444 \\
\hline Malay & 19 & --- & --- & 1 & --- & --- & 1 \\
\hline Mozambique & --- & --- & --- & --- & --- & 105 & 146 \\
\hline Nias & 45 & 20 & 14 & 15 & 23 & 83 & 41 \\
\hline Other ${ }^{\mathrm{c}}$ & 22 & --- & --- & --- & --- & --- & --- \\
\hline Total & 210 & 140 & 258 & 162 & 335 & 819 & 914 \\
\hline
\end{tabular}

Notes: a Adults only; ethnicity of children not specified.

${ }^{\mathrm{b}}$ Locally-born.

c Includes slaves identified as Batta [sic], "Transport," or "Malefactor."

Sources: G/35/8, fols. 225, 438r-439v; G/35/9, fols. 131r-133v, 177r-180r; G/35/10, fols. 121r-124v; G/35/14, fols. 87r-98r; G/35/23, [No. 32], List of the Honble Companies Slaves at Fort Marlbro and its Dependencies.

It is difficult to determine how many slaves reached Bencoolen. Slave censuses did not always report the number of slaves at the factory's substations and are silent about slave births and deaths (Table 2). Information about the number of slaves shipped to the settlement exists for only nine of the known company-sanctioned slaving voyages destined for Sumatra between the 1690 s and early 1770s. These ships delivered a total of 873 slaves, mostly Malagasies, between 1714 and 1765 in groups that ranged in size from fewer than 20 to as many as $199 .{ }^{23}$ Slaves also reached the settlement in other ways. Officials bought slaves individually or in small groups from persons who called at or lived near the settlement. Such was the case in 1712, when they purchased a twenty-five-year-old Malabar man named January for $\$ 50 ;{ }^{24}$ in 1731 , when they secured the services of 
Andrew, a Malabar boatman, for $\$ 60,{ }^{25}$ in 1739 , when they paid $\$ 50$ each for 12 "able stout men" from a group of 25 Nias slaves offered to them, ${ }^{26}$ in 1762, when they acquired a Coffree woman and six Coffree men from various parties for $\$ 660 ;{ }^{27}$ and in 1772 , when they purchased 29 Balinese men, women, and children for $\$ 1,190$, perhaps from one of the Chinese merchants who traded slaves in the region. ${ }^{28}$

Table 2

Slave population at Bencoolen and dependencies, 1709-1794

\begin{tabular}{|c|c|c|c|c|c|}
\hline Year & $\underline{\text { Men }}$ & Women & $\underline{\text { Boys }}$ & $\underline{\text { Girls }}$ & $\underline{\text { Total }}$ \\
\hline$\overline{1709}$ & $\overline{---}$ & --- & -- & $\overline{---}$ & $\overline{235}$ \\
\hline 1712 & 81 & 64 & \multicolumn{2}{|c|}{-------- 45 ---------- } & 190 \\
\hline 1713 & 79 & 65 & 14 & 30 & 188 \\
\hline c. 1716 & --- & --- & --- & --- & 394 \\
\hline 1718 & $170^{\mathrm{a}}$ & $126^{\mathrm{a}}$ & \multicolumn{2}{|c|}{--------- 4 ---------- } & 300 \\
\hline 1725 & \multicolumn{2}{|c|}{---------237--------- } & \multicolumn{2}{|c|}{---------30---------- } & 267 \\
\hline 1727 & --- & --- & --- & --- & 217 \\
\hline 1730 & 77 & 63 & 17 & 9 & 166 \\
\hline 1733 & 85 & 57 & 12 & 15 & 169 \\
\hline 1737 & 104 & 61 & 13 & 14 & 192 \\
\hline 1742 & 85 & 104 & 38 & 31 & 258 \\
\hline $1748^{\mathrm{b}}$ & $75 / 82$ & $83 / 87$ & $26 / 32$ & $30 / 36$ & $214 / 237$ \\
\hline 1755 & 146 & 210 & 39 & 37 & 432 \\
\hline 1756 & 141 & 179 & 48 & 36 & 404 \\
\hline 1758 & 182 & 196 & 49 & 31 & 458 \\
\hline 1759 & 187 & 199 & 40 & 34 & 460 \\
\hline 1766 & 481 & 217 & 121 & 43 & 862 \\
\hline 1767 & 482 & 248 & 128 & 44 & 902 \\
\hline 1768 & 467 & 256 & 103 & 53 & 879 \\
\hline 1770 & 439 & 274 & 96 & 53 & 862 \\
\hline 1778 & 497 & 398 & 125 & 101 & 1,121 \\
\hline 1782 & 371 & 334 & 112 & 93 & 910 \\
\hline 1785 & 302 & 266 & 63 & 76 & 707 \\
\hline 1786 & 285 & 261 & 66 & 74 & 686 \\
\hline 1794 & 123 & 147 & 49 & 42 & 361 \\
\hline
\end{tabular}


Notes: a Includes "lusty" boys/girls, i.e., probably adolescents or late adolescents.

${ }^{\mathrm{b}}$ Two sets of census figures for this year.

Source: Allen, 2014a, pp. 224-25; G/35/9, fols. 131r-133v.

The fort's chattel population also included men, women, and children transferred to Sumatra from other company establishments. The first transfer from St. Helena may have occurred as early as 1687 following the directors' order that 10 English-speaking blacks from the island were to be sent to Sumatra. ${ }^{29}$ The first such transfer from India may have occurred circa 1700 when the company's Court of Directors ordered that any spare Coffrees at Fort St. David (Tegnapatam) on the Coromandel Coast be sent to Bencoolen. ${ }^{30}$ The 25 confirmed slave transfers from Banjarmasin (Borneo), Bombay, Calcutta, Madras, St. Helena, and Tegnapatam to Bencoolen delivered at least 600 men, women, and children to the settlement (Allen, 2014a, p. 58). Fort Marlborough also sent small numbers of slaves to other company establishments, often to be trained as craftsmen and artisans and as a punishment for serious crimes. The largest such transfer occurred in 1787 when 129 slaves were shipped to the recently-established company settlement at Penang to meet the demand for labor there, 125 of whom reached their destination alive. ${ }^{31}$

\section{"They are Humane Creatures"}

In January 1713, the Court of Directors dispatched a letter to Bencoolen on the Arabella whose captain was also charged with acquiring 200 Malagasy slaves for the settlement. ${ }^{32}$ In their letter, the directors admonished local officials to house, feed, and clothe the men, women, and children in their charge properly because, they asserted, "they are humane [sic] Creatures." 33 Four years later, the directors likewise enjoined officials on St. Helena to use their slaves "humanely" because, they noted, "they are Men." ${ }^{34}$ Subsequent letters to Fort Marlborough, Fort St. David, and Bombay during the 1730s and 1750s included similar language and admonitions. ${ }^{35}$ 


\section{Allen-Slavery in a Remote but Global Place}

The January 1713 letter was not the first time that officials at Bencoolen received instructions about how to treat their chattel laborers. In August 1687, the company's directors had observed that dry and comfortable lodgings needed to be erected for York Fort's slaves "if you think to keep them serviceable and in health." "36 Three years later, the directors advised factory officials that in addition to employing their slaves "prudently," they wanted them used leniently and to have full bellies and adequate lodging. Such practices, the directors continued, would not only help to preserve their lives and health, but also encourage them to increase and multiply, to which end adult males were to be allowed a wife of "their own Cast [sic]." ${ }^{37}$ Bencoolen's managers probably had these instructions in mind when, in 1695, they debated regulations governing slaves' use and care, one consequence of which was to order that the food, clothing, and cash allowances allocated to most slaves would henceforth be given to all slaves, while particularly ingenious and industrious slaves were to be eligible for cash rewards. ${ }^{38}$ Fourteen years later, the directors admonished York Fort's managers to take care that all of the settlement's inhabitants, including its slaves, had fit food and lodging, and that they were well looked after when they became sick. ${ }^{39}$

Implicit in these regulations was an understanding, subsequently articulated in the Court's January 1713 letter, that treating company slaves well was economically advantageous: "they are likely to be more beneficial to our Affairs the longer they live." ${ }^{40}$ Later correspondence reflected similar attitudes. The Court's instructions in March 1740 that Bencoolen's slaves were to be employed constantly to the company's benefit were clearly premised on the belief that only fairly treated and properly fed, clothed, and housed men and women would be able to work full time. ${ }^{41}$ What is known about the structure and organization of the factory's chattel work force provides additional, albeit circumstantial, evidence that economic selfinterest influenced such attitudes. Craftsmen comprised at least 25 percent and sometimes as much as 42 percent of "effective" adult male slaves between 1730 and 1786, ${ }^{42}$ and company officials, who the Court admonished regularly to control costs, were undoubtedly loath to risk the time, effort, and money invested in training these much needed skilled workers.

This concern is all that much more striking given that these sentiments were expressed at a time when Europeans rarely openly acknowledged their 


\section{HSE - Social and Education History, 7(2) 161}

slaves' humanity. That the Court expressed these sentiments explicitly in the 1710 s and then again during the 1730s and 1750s comes, however, as no surprise. Michael Fisher $(2004,2006)$ has detailed the company's efforts during the eighteenth century to alleviate the condition of the Indian and other Asian sailors stranded in England by their captains and return them to their homelands, while various sources attest to the company's long-term commitment to having the slaves transported on its ships reach their destination in good health (Allen, 2014a, pp. 50-54). This humanitarianism continued to manifest itself after Bencoolen's cession to the Dutch in 1825, when company officials sought to intercede on behalf of the freed slaves who had elected to remain at the settlement but then changed their minds and sought repatriation to company settlements at Penang and Singapore. ${ }^{43}$

Evidence of the extent to which local officials heeded these admonitions is limited mostly to the 1710 s. Late in 1714 , the factory's managers not only assured their corporate masters that they took "all possible care" of the slaves in their charge, but also hastened to report that the fort's doctor tended to them when they were sick and that only their overseers were permitted to strike them. ${ }^{44}$ Four years later, Stephen Newcome and his council averred that no slaves were "more kindly treated," that they received their full allowances of food, clothing, and incidental spending money, and that they were treated mercifully even for crimes such as murder. ${ }^{45}$ Scattered references to slaves' treatment after the 1710 s adopt the same general tone, as in 1753, when the Court received news that the number of buffaloes given to slaves each month for food had been increased to eight. ${ }^{46}$

Instructions to treat the factory's slaves humanely did not, of course, guarantee that they experienced a better quality of life than elsewhere in the European slave-owning world. The archival record includes references to slave quarters being dilapidated and slaves being inadequately clothed and poorly fed because supplies had not arrived from India. The same sources also indicate that local officials often attempted to rectify these problems in a timely, albeit not necessarily long-lasting, manner. A 1695 report that slave huts were "irregularly built" and intermingled among the dwellings of the settlement's resident Portuguese prompted a proposal to tear the huts down and construct new ones within an enclosed paggar, or compound, near the waterfront ${ }^{47}$ Sixteen years later, however, the Coffree paggar had become so ramshackle that it needed to be relocated. ${ }^{48}$ In August 1714, the fort's 


\section{Allen - Slavery in a Remote but Global Place}

paymaster received an advance of $\$ 450$ to build 30 huts to house the 167 Malagasy slaves who had just arrived on the Clapham $;{ }^{49}$ later that year local officials informed London that they were building 60 huts to accommodate the 199 slaves brought by the Arabella. ${ }^{50}$ However, these structures' durability apparently left something to be desired; early in 1719, the Court noted that the few houses in the slave compound in good condition had been repaired or rebuilt by slaves themselves with materials they had stolen. ${ }^{51}$

Other sources likewise attest to a willingness to take steps to ensure this population's well-being. A 1709 report that the factory's slaves were poorly clothed because suitable cloth had not arrived from India prompted the purchase locally of a small quantity of ordinary ginghams as a temporary solution to the problem. ${ }^{52}$ Similar problems in $1711,1715,1726,1727$, and 1755 elicited comparable responses. ${ }^{53}$ In other instances, however, slaves paid the price of the settlement's dependence on supplies from India. In 1745, the possibility that much needed supplies would not arrive from India led to a reduction in slaves' monthly rice allowance. ${ }^{54}$ Twelve years later, both the factory's garrison and slaves faced reduced rations because the surrounding countryside could not furnish sufficient rice to compensate for the supplies that had failed to arrive from India, a problem compounded by the fort's lacking adequate quantities of salt to trade for whatever rice might be had locally. ${ }^{55}$

If company officials sought, at least in principle, to treat factory slaves in a humane manner, these men, women, and children nevertheless remained subject to exploitation and abuse. In 1721, the widespread sexual exploitation of women slaves, often under the guise of having them cook, clean, sew, and wash clothing for the settlement's European residents, spurred official attempts to squelch such "public debauchery." ${ }^{56}$ Slaves were also clearly subject to violence, as in 1711, when Flyamango, a Coffree slave who had been regularly abused and beaten severely, was beaten to death after a failed attempt to escape, and in 1765, when a British sailor killed a Coffree man during an unsuccessful attempt to rape a Coffree woman. ${ }^{57}$ Slaves retaliated in kind, as in 1735 , when a slave woman named Hannah was found guilty of poisoning the fort's armorer, a crime for which she was sentenced to be flogged 39 times at each of three places and then kept in irons until she could be transported to Madras. ${ }^{58}$ Slaves also inflicted violence on fellow slaves, as in 1755 , when Nias slaves murdered two slave 
boys belonging to Reverend Neil, ${ }^{59}$ in 1770 , when a Coffree slave named Jack murdered the Coffree woman Nanny, ${ }^{60}$ and in 1780 when a Coffree man seriously wounded a Coffree woman after she refused his advances. ${ }^{61}$

Bencoolen's slaves resisted their captivity in various ways that included smoking bhang (marijuana) cultivated by the local Chinese community when they could obtain it. ${ }^{62}$ The most public manifestation of slave resistance, however, was maroonage, often toward Dutch-controlled territory. ${ }^{63}$ In 1711, officials asserted that the slave paggar's decrepit condition and the ready access that slaves had to local Malays facilitated desertions. ${ }^{64}$ The consternation that such activity could arouse is revealed by a 1745 report in which Edward Hurlock noted not only that four of the slaves in his charge (two men and two women) at Moco Moco were missing, but also that an Italian priest had told him of a village near Palembang inhabited by runaway Coffrees. The maroon village's existence prompted Hurlock to express his concern that Sampson and Lymar, the two male escapees in question, both of whom had frequently run away before, might reach this settlement from which they could subsequently "return and encourage others to follow their Example, which he cannot guard against, as the Mallays [sic] are afraid to attempt the seizing of them." ${ }^{\text {"W }}$ While most slaves apparently fled individually or in small groups of two to four persons, they also did so in much larger numbers. In February 1715, at least 19 and perhaps as many as 30 men and women escaped together toward Moosee [sic], 90 miles away across the mountains, in the hope of reaching "their own country." 66 Other larger-scale escapes may also have occurred in 1727, 1737, 1739, 1762, and $1767 .{ }^{67}$ While fugitive slaves were often recovered, some, such as the eight Malabars who escaped from the fort's hospital in 1737, apparently eluded capture.

The activities of a group of fugitives in 1776 offer a rare glimpse into the dynamics of slave society at Bencoolen. These maroons seized a prau which they sailed to Lenow [sic] where they set fire to the guard house and pepper warehouse in an attempt to rescue three of their comrades who had been arrested by the station's manager. ${ }^{68}$ Isolated reports of slaves purchasing the freedom of family members provide additional evidence of such social cohesion. In 1714, Congalo, a Bengali slave, petitioned successfully to purchase the freedom of his three-year-old and six-month-old granddaughters for $\$ 20$ and then of his twenty-four-year-old daughter, Jenny 


\section{Allen - Slavery in a Remote but Global Place}

Kitty, for $\$ 45 .{ }^{69}$ Four years later, an "old" company slave, Sreelaugah, paid $\$ 40$ to free his seven-year-old daughter Goongah even though she was valued at only $\$ 20 .{ }^{70}$ Other sources suggest that slaves and freedmen of the same ethnicity or place of origin maintained a sense of community identity. Such seems to have been particularly true of those from Nias. "Nias people" purchased the freedom of Aneckee, an aged and infirm countryman, in 1732 for \$50; of Peenore, an aged and infirm countrywoman, in 1735 for \$25; and of an unnamed four-year-old child in 1741 for $\$ 15 .{ }^{71}$ The sense of community implicit in these acts remained intact more than 40 years later when officials observed that Nias slave women rarely reported the birth of their newborn children who they gave to manumitted relatives and friends to be nursed and raised. ${ }^{72}$

\section{The Winds of Abolitionism}

Although slavery remained an integral part of life at Bencoolen throughout the eighteenth century, the mid-1780s found the factory beginning to be buffeted by the abolitionist sentiments that became part of company discourse until Act V of 1843 formally abolished slavery in the Indian territories under the company's control (Major, 2012; Allen, 2014a, pp. 179220). On 20 March 1786, Acting Governor-General John Macpherson and his council proposed emancipating those of the settlement's slaves capable of supporting themselves, ${ }^{73}$ the first such proposal of its kind anywhere in the company's possessions. The proposal elicited the Court of Directors' approval; in doing so, the Court included instructions that, once manumitted, the settlement's new freedmen, who were expected to provide their labor for the company when needed or grow pepper, were to be paid at the "usual rate," while aged and infirm slaves were to receive a small annual pension so they would not want for the necessities of life. ${ }^{74}$ The Court's letter had, moreover, been approved by the Board of Commissioners for the Affairs of India, commonly-known as the Board of Control or the India Board, before being dispatched to Sumatra. The board, established by the India Act of 1784 to bring the company's civil, financial, and military affairs under direct governmental supervision, was composed of cabinet ministers and privy councilors who reviewed and amended, if necessary, the Court's draft correspondence. The board members who sanctioned the emancipation 
proposal at Bencoolen included Prime Minister William Pitt the Younger, Henry Dundas, who would play an important role in killing the parliamentary bill of 1792 to abolish the British slave trade, and William Grenville, on whose watch as prime minister (1806-07) Parliament ultimately abolished the British slave trade. ${ }^{75}$

The reasons for this growing humanitarian concern in the company about slavery and slave trading beginning in the mid-1780s remain less clear. Recent scholarship on the connections between calls to reform the British establishment in India and an imperially-inspired evangelical abolitionism suggests that the proposal to emancipate Bencoolen's slaves may reflect, at least in part, a desire to improve the company's image in Britain (WymanMcCarthy, 2014). There can be little doubt that the proposal to emancipate Bencoolen's slaves was closely linked to at least two practical concerns: the cost of maintaining slaves at a time when the company sought to reduce expenses, and changing perceptions about the cost-effectiveness and efficiency of slave labor. In the first instance, the minutes of the meeting at which slave emancipation at Bencoolen was first proposed noted that doing so would spare the company the substantial expense of caring for this work force; in 1785, those expenses had totaled $\$ 26,000$, or more than 11 percent of the factory's annual budget. ${ }^{76}$ Isolated reports from the late 1750 s suggest that such costs could easily be higher. The $\$ 520$ spent to maintain slaves each month in 1757, for example, accounted for 22 percent of total monthly expenditures; ${ }^{77}$ the following year, the $\$ 544$ spent on slaves each month equaled 14.6 percent of all monthly expenditures. ${ }^{78}$ The magnitude of these expenses is revealed in other ways. In 1779, Philip Mannington called for an end to the practice, which cost $\$ 3,800$ a year, of giving slaves a buffalo twice a month for food. It would be much less expensive, as well as much more agreeable to the slaves themselves, he opined, to give them a cash grant each month to meet their needs. Doing so, he asserted, would save $\$ 2,000$ a year, while clothing slaves with textiles imported from Madras rather than locally purchased cloth would save another $\$ 1,200$ to $\$ 1,400$ each year. ${ }^{79}$ Eight years later, the dispatch of 129 of Bencoolen's slaves to Penang was calculated to save the settlement $\$ 9,288 .{ }^{80}$

The structure and composition of the fort's slave population and its attendant inability to meet the demand for laborers made these expenses even more burdensome. In 1758, almost 25 percent of the settlement's 237 


\section{Allen - Slavery in a Remote but Global Place}

adult slaves were described as "superannuated." 81 Twenty-eight years later, more than 18 percent of the factory's 658 slaves were either superannuated or children too young to work. ${ }^{82} \mathrm{~A}$ request by the manager of the settlement's sugar plantation at Benteerin several months later for 30 Coffrees emphasized that the estate lacked an adequate number of workers because most of the 49 slaves who had died or been disabled during the preceding three years had never been replaced. ${ }^{83}$ Census data confirm that the settlement's slave population declined dramatically in size between 1778 and 1786 (Table 2).

The 1786 proposal to turn these potential freedmen into wage laborers and independent pepper planters capable of supporting themselves heralded a significant, albeit subtle, shift in company attitudes about the efficiency of slave labor. Four years later, company directors again signaled their belief in the superiority of free labor when they commended Calcutta's efforts to ensure that the presidency's peasant farmers enjoyed "the fruits of their industry," ${ }^{84}$ sentiments they repeated the following year to Madras. ${ }^{85}$ The company's chairman espoused similar views in 1796 when he observed that "slaves cannot work so cheap as free men, besides we ought to give all our subjects liberty." 86

Despite Calcutta and London's support, the plan to emancipate Bencoolen's slaves soon foundered over concern about the deleterious economic and socio-political consequences of such an undertaking. In May 1787 , local officials observed that it would be "impolitic and dangerous" to emancipate any of the fort's slaves, in part because they would be unable to grow pepper or support themselves by "handicraft Trades." ${ }^{87}$ Five weeks later, the settlement's chief, while acknowledging that this plan may have been inspired "by Benevolence," argued against it on the grounds that such freedmen "would from the Indolence they have Contracted as Company's slaves become a Pest to the Settlement and instead of Supplying Necessities, would more like Rob and Plunder for Subsistence." 88 In the face of this continued opposition, ${ }^{89}$ the Court withdrew its support for the plan in May $1790,{ }^{90}$ as a result of which Bencoolen's slaves would not taste freedom for many more years to come.

It was in this context of labor shortages and possible slave emancipation that Bencoolen became, in 1787, the site of the first company experiment with Indian convict labor. The VOC had pioneered the use of such labor in 
the Indian Ocean world by shipping Ceylonese, Chinese, and Javanese prisoners to the Cape of Good Hope within several years of that colony's establishment in 1652, a practice that continued well into the eighteenth century (Ward, 2009; Armstrong, 2012). The British were also no strangers to using such labor, having transported some 50,000 convicts to their American colonies between 1718 and 1775 (Grubb, 2000; Forster, 2002). Concern about the threat that crime posed to public order and ultimately their authority in India encouraged company officials to view convict transportation as a way both to enhance their political legitimacy by publically demonstrating their commitment to law and order, and to meet the demand for inexpensive labor at company establishments. In 1806, Thomas Parr emphasized the cost-effectiveness of such labor when he informed Calcutta that convict laborers at Bencoolen cost only $\$ 3 \frac{1}{2}$ a month to maintain compared to the $\$ 5$ to $\$ 6$ required to hire free Malays. This lower cost prompted Parr to propose that convicts be used to cultivate coffee and nutmegs as well as laboring on public works. Such an undertaking, Parr continued, would allow the settlement to export large quantities of coffee, nutmeg, and mace, the sale of which, he estimated, would yield the settlement and the company profits of $£ 124,500$ and $£ 422,700$, respectively. ${ }^{91}$

A minimum of 2,000 and perhaps as many as 4,000 to 6,000 Indian convicts reached Bencoolen between 1787 and 1825. A directive in 1800 that convicts working for the fort's engineer would be subject to the same regulations as the settlement's Coffrees underscores the ways in which these two labor systems were intertwined. ${ }^{92}$ Bencoolen's success in using convicts to labor on public works led to large numbers of these individuals being sent to the Straits Settlements (Malacca, Penang, Singapore) as well as the Andaman Islands, Burma, and Mauritius. The total number of convicts transported from India remains a subject of debate, but British authorities dispatched at least 74,800 and perhaps 100,000 or more such prisoners overseas between 1787 and 1943, mostly during the first two-thirds of the nineteenth century (Anderson, 2000, 2007a, 2007b, 2012; Sen, 2000; Yang, 2003; Rediker, Pybus, \& Christopher, 2007). 


\section{Slavery at Bencoolen in Perspective}

More than 35 years ago, Nigel Bolland (1981) noted that some of our best insights into how European colonial empires, and colonial labor systems in particular, functioned come from exploring developments on the periphery of empire rather than in imperial centers. Bolland's astute observation, a product of his research on indentured labor relations in the nineteenthcentury British West Indies, is equally relevant to attempts to understand slavery and forced labor in European establishments in the Indian Ocean and East Asia. As the Bencoolen case study demonstrates, it is in such an ostensibly remote place on the fringes of its far-flung commercial empire that the company's experience with slavery and slave labor is revealed in greatest detail. In so doing, the Bencoolen case study highlights the need to examine slavery in other European company establishments in the Indian Ocean world. We know very little about slavery and slave trading in the French Compagnie des Indes' comptoirs in India such as Chandernagore, Karikal, Mahé, Pondichéry, and Yanam even though these settlements funneled an estimated 24,000 enslaved Indians towards the Mascarene Islands of Mauritius and Réunion between the late seventeenth century and 1810 (Allen, 2004, p. 41). While the VOC's experience with slavery is a subject of ever greater scholarly interest (e.g., Vink, 2003; Raben, 2008; Van Welie, 2008; Ward, 2009; Jones, 2010), many aspects of this activity remain hidden from view.

If the Bencoolen case study deepens our understanding of the EIC's experience with chattel labor, the picture that emerges from this microcosm remains incomplete not only because of the evidentiary problems noted earlier, but also because of the historiographical propensity to examine migrant labor systems, whether "free" or "unfree," in this and other oceanic worlds in isolation from one another. Clare Anderson's perceptive discussion (2009) of the similar ways in which British officials thought about and processed convict and indentured laborers during the early nineteenth century demonstrates that this "tyranny of the particular" in labor studies is no longer sustainable (Allen, 2017). New insights into the origins of the indentured labor trades that scattered more than 2.2 million Africans, Chinese, Indians, Japanese, Javanese, and Melanesians throughout and 
beyond the colonial plantation world between the 1830s and 1920s underscore this point (Allen, 2014b).

As Bencoolen's consultations and correspondence with London and India demonstrate, future discussions about free and unfree migrant labor in the eighteenth- and early nineteenth-century Indian Ocean world must also transcend the current preoccupation with enslaved Africans and indentured Indians to include the tens of thousands of Chinese and other Asians who also participated in these labor trades. Scholarship on Chinese labor migration has hitherto focused largely on the years after circa 1850 (McKeown, 2004). However, as Craig Lockard (2013) reminds us, Chinese labor migration to Southeast Asia has a much longer history. The ways in which Chinese participated in the increasingly intertwined slave, convict, and indentured labor trades that are a hallmark of late eighteenth- and early nineteenth-century global history remain largely unexplored. The need to do so is highlighted by tantalizing clues found in the EIC's archives. In 1706, for example, the residents of the company's factory at Banjarmasin in Borneo included 70 Chinese laborers as well as 50 slaves, 37 Javanese workers, and 9 European craftsmen. ${ }^{93}$ Fifty-seven years later, the Court of Directors "hinted" to Calcutta that the Admiral Watson, about to sail from England to Sumatra, could be used to procure Chinese laborers as well as Malagasy or other slaves for Bencoolen. ${ }^{94}$ As the company's subsequent involvement in securing Chinese laborers for Trinidad and Ceylon at the beginning of the nineteenth century demonstrates (Allen, 2014a, pp. 198201), officials in London and the Indian Ocean, unlike many modern historians, understood that satisfying the need for labor could easily encompass the entire globe and the diverse populations that inhabited

\section{Notes}

${ }^{1}$ India Office Records, British Library, London: E/3/91, pp. 4, 25, 27-28, 35. All other archival citations are from these records.

${ }^{2}$ E/3/91, pp. 352, 356, 385.

${ }^{3} \mathrm{E} / 3 / 91$, p. 378.

${ }^{4} \mathrm{G} / 35 / 1$, pp. 61-62.

${ }^{5} \mathrm{G} / 35 / 7$, p. 3 .

${ }^{6} \mathrm{G} / 35 / 7$, p. 184; G/35/11, fol. 206v (para. 24). 


\section{Allen - Slavery in a Remote but Global Place}

${ }^{7} \mathrm{G} / 35 / 13$, fols. 4v, 273v.

${ }^{8}$ G/35/17, [No. 110], Philip Mannington to Court of Directors, 8 June 1779, section headed "Charges Slaves"; G/35/54, John Crisp, Robert Hamilton, and Phillip Braham to Charles Earl Cornwallis, 24 March 1792; G/35/99, p. 113; G/35/112, Fort Marlborough Consultation [hereafter FMC], 14 December 1807, R.S. Perreau to Thos Parr, 12 December 1807.

${ }^{9}$ E.g., G/35/5, Rich ${ }^{\mathrm{d}}$ Watts, Geo. Shaw \& Rob ${ }^{t}$ Broughton, York Fort, to the Hon ${ }^{\text {ble }}$ Gov $^{r}$

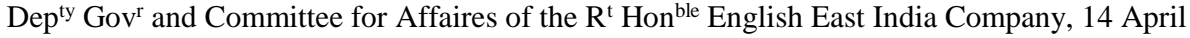
1701 (para. 14); G/35/162, fols. 53r-54v.

${ }^{10}$ G/35/56, fol. 31, York Fort Consultation [hereafter YFC], February 1705.

${ }^{11} \mathrm{G} / 35 / 58$, FMC, 20 December 1722.

${ }^{12} \mathrm{G} / 35 / 71$, [1762 Consultations], fol. 26.

${ }^{13}$ G/35/6, Richard Skingle et al. to Court of Managers, 2 January 1708.

${ }^{14} \mathrm{G} / 35 / 9$, fols. 211-212r (para. 15); E/3/110, p. 340 (para. 5).

${ }^{15}$ G/35/16, [No. 118], Robert Hall et al. to Court of Directors, 24 July 1776 (para. 17).

${ }^{16} \mathrm{G} / 35 / 90$, fols. 9-10.

${ }^{17} \mathrm{E} / 3 / 90$, p. 4 (para. 14).

${ }^{18}$ E/3/98, p. 257 (para. 4).

${ }^{19}$ E.g., E/3/102, p. 517 (para. 18); E/3/103, pp. 164-65 (paras. 27-28); E/3/104, p. 37 (para. $10)$.

${ }^{20}$ E.g., G/35/60, FMC, 26 September 1728, 19 November 1728; G/35/61, FMC, 13 July 1734, 8 August 1734; G/35/63, FMC, 11 May 1741, 7 August 1742; P/240/1, Fort St. George Public Consultation, 12 September 1733, 28 October 1734; G/35/14, fol. 17v (para. 73).

${ }^{21} \mathrm{E} / 3 / 95$, p. 584 (para. 12); E/3/97, p. 184 (para. 104); E/3/102, p. 517 (para. 18); G/35/7, p. 126; G/35/12, fol. 810r, (para. 22).

${ }^{22}$ Allen, R.B. Unpublished British East India Company slaving voyage inventory, vers. 26 August 2017.

${ }^{23} \mathrm{G} / 35 / 7$, pp. $126-27$ (para. 3), 129 (para. 4); G/35/9, fol. 88r; G/35/13, fols. 331v-332r; G/35/71, p. 13; G/35/73, p. 279, 412; L/MAR/B/385A; L/MAR/B/622B.

${ }^{24} \mathrm{G} / 35 / 57$, YFC, 22 May 1712.

${ }^{25}$ G/35/61, FMC, 29 September 1731.

${ }^{26} \mathrm{G} / 35 / 62$, [1739 section], p. 15 .

${ }^{27} \mathrm{G} / 35 / 71$, [1762 section], fols. 24-25.

${ }^{28}$ G/35/79, FMC, 18 January 1772. On Chinese merchants carrying Balinese slaves to Batavia, see Knaap and Sutherland, 2004, p. 153.

${ }^{29} \mathrm{E} / 3 / 91$, p. 352.

${ }^{30} \mathrm{E} / 3 / 93$, p. 343 (para. 12).

${ }^{31} \mathrm{G} / 35 / 52$, Letter from Bengal to Fort Marlborough dated 22d December 1786; G/34/2, pp. 574-87.

${ }^{32} \mathrm{E} / 3 / 98$, pp. $260-62$.

${ }^{33} \mathrm{E} / 3 / 98$, p. 257 (para. 3).

${ }^{34} \mathrm{E} / 3 / 99$, p. 494 (para. 57).

${ }^{35}$ E/3/106, pp. 25-26; E/3/116, [Court of Directors to] Fort Marlborough, 23 November 1733 (para. 8); E/3/111, p. 210; E/3/111, p. 385.

${ }^{36} \mathrm{E} / 3 / 91$, p. 385. 
${ }^{37}$ E/3/92, p. 120 (para. 4).

${ }^{38} \mathrm{G} / 35 / 3$, pp. 34, 40 .

${ }^{39} \mathrm{E} / 3 / 96$, p. 761 (para. 19).

${ }^{40}$ E/3/98, p. 257 (para. 3).

${ }^{41}$ E/3/118, [Court of Directors to] Fort Marlborough, 28 March 1740 (para. 7).

${ }^{42} \mathrm{G} / 35 / 8$, fols. 438r-439v.; G/35/9, fols. 221r-224r; G/35/10, fols. 121r-124v, 126r; G/35/11, fol. 424; G/35/23, [No. 75], List of Slaves belonging to the Honble Comp ${ }^{\mathrm{y}}$ under the Superintendant [Fort Marlbro, $16^{\text {th }}$ March 1786].

${ }^{43}$ F/4/1184/30747, Correspondence with the Governments of the Netherlands Possessions in India and of Prince of Wales Island $\&^{c}$ respecting the removal from Bencoolen of certain Free Bengalees, and others, who were left there at the cession of that Place to the Dutch; F/4/1307/51937, Further Correspondence relative to the removal of emancipated Slaves and Convicts at Bencoolen....

${ }^{44} \mathrm{G} / 35 / 7$, p. 129 (para. 6).

45 G/35/7, p. 184 (para. 92).

$46 \mathrm{E} / 4 / 5$ p. 437.

${ }^{47} \mathrm{G} / 35 / 3$, p. 35 .

${ }^{48}$ G/35/57, YFC, 13 April 1711.

${ }^{49}$ G/35/57, YFC, 12 August 1714.

${ }^{50} \mathrm{G} / 35 / 7$, p. 129 (para. 6).

${ }^{51}$ E/3/100, p. 315 (para. 55).

${ }^{52}$ G/35/56, FMC, 19 November 1709.

${ }^{53}$ G/35/57, YFC, 3 July 1711, 27 June 1715; G/35/59, FMC, 20 August 1726; G/35/60, FMC, 3 May 1727; G/35/68, FMC, 1755.

${ }^{54} \mathrm{G} / 35 / 64$, p. 312 .

$55 \mathrm{G} / 35 / 11$, fol. $47 \mathrm{r}$.

${ }^{56}$ G/35/58, Diarys \& Consultations att Bencoolen Factory, April 1721; G/35/67, pp. 178-85.

${ }^{57}$ G/35/57, York Fort Diary, entry after 18 March 1712, Stephen Bailhon to John Hunter, 13 March 1712; G/35/73, p. 4.

${ }^{58}$ G/35/61, FMC, 21 April 1735, 28 April 1735.

${ }^{59} \mathrm{G} / 35 / 10 \mathrm{~A}$, p. 78 (para. 48 ).

${ }^{60} \mathrm{G} / 35 / 78$, pp. $28-32$.

${ }^{61} \mathrm{G} / 35 / 85$, p. 164.

${ }^{62}$ G/35/62, [1738 section], p. 124; G/35/67, FMC, 8 July 1758.

${ }^{63} \mathrm{G} / 35 / 73$, p. 163 .

${ }^{64} \mathrm{G} / 35 / 57$, YFC, 13 April 1711.

65 G/35/64, pp. 216-17.

${ }^{66} \mathrm{G} / 35 / 7$, p. 137 (paras. 79-81).

${ }^{67}$ G/35/60, FMC, 24 October 1727; G/35/62, [1738 section], p. 118, and [1739 section], p. 15; G/35/75, p. 132.

${ }^{68}$ G/35/16, [No. 118], para. 9, Robert Hall et al. to Court of Directors, 24 July 1776.

${ }^{69}$ G/35/57, YFC, 18 February 1713/14, 28 April 1714.

${ }^{70}$ G/35/58, FMC, 12 July 1718. 


\section{Allen - Slavery in a Remote but Global Place}

${ }^{71}$ G/35/61, FMC, 13 November 1732, 29 January 1734/5; G/35/63, FMC, 21 February $1740 / 1$.

$72 \mathrm{G} / 35 / 89$, fol. 402 .

${ }^{73} \mathrm{G} / 35 / 156$, fol. $55 \mathrm{v}$.

${ }^{74}$ F/3/3, p. 108 (para. 5).

${ }^{75}$ F/3/3, p. 108 (para. 5). See also Blackburn, 1988, pp. 146, 150, 306-15, 466.

${ }^{76} \mathrm{G} / 35 / 156$, fol. $42 \mathrm{v}$.

${ }^{77} \mathrm{G} / 35 / 11$, fol. $186 \mathrm{v}$.

${ }^{78} \mathrm{G} / 35 / 11$, fol. $425 \mathrm{v}$.

${ }^{79}$ G/35/17, No. 110, Section head: "Charges slaves," Philip Mannington to Court of Directors, 8 June 1779.

${ }^{80} \mathrm{G} / 35 / 90$, fol. 491.

${ }^{81}$ G/35/11, [No. 535], A List of Slaves \& Transports belonging to the Honourable Company at Fort Marlbro \& its Dependencies, 21 February 1758.

${ }^{82}$ G/35/23, [No. 75], List of Slaves belonging to the Honble Comp ${ }^{y}$ under the Superintendant [Fort Marlbro, 16 ${ }^{\text {th }}$ March 1786].

${ }^{83} \mathrm{G} / 35 / 89$, fol. 184 .

${ }^{84}$ F/3/5, No. 765 (para. 55), Draft Paragraphs...of Fort William in Bengal [before 8 May 1790].

${ }^{85}$ F/3/36, No. 902, Draft Paragraphs... of Fort $S^{t}$ George [before 2 May 1791].

${ }^{86}$ David Scott to Herbert Harris, Calcutta, 16 May 1796, in Philips, 1951, p. 76.

${ }^{87} \mathrm{G} / 35 / 90$, fols. 219-20.

${ }^{88} \mathrm{G} / 35 / 157$, pp. $21-22$.

${ }^{89} \mathrm{G} / 35 / 52$, Letter from Bengal to Fort Marlborough dated 31 ${ }^{\text {st }}$ March 1788; G/35/158, pp. $170-74$.

${ }^{90}$ G/35/43A, p. 126. The Board of Control approved this draft letter three days later.

91 F/4/259/5666, pp. 28-33, 36-37. Calcutta subsequently approved Parr's proposal (F/4/259/5666, pp. 78-79).

$92 \mathrm{G} / 35 / 100$, p. 114.

$93 \mathrm{G} / 35 / 7$, p. 39.

${ }^{94}$ E/4/617, p. 702.

\section{References}

Allen, R.B. (2004). The Mascarene slave-trade and labour migration in the Indian Ocean during the eighteenth and nineteenth centuries. In $\mathrm{G}$. Campbell (Ed.), The structure of slavery in Indian Ocean Africa and Asia (pp. 33-50). London: Frank Cass.

Allen, R.B. (2014a). European slave trading in the Indian Ocean, 15001850. Athens, $\mathrm{OH}$ : Ohio University Press. 
Allen, R.B. (2014b). Slaves, convicts, abolitionism and the global origins of the post-emancipation indentured labor system. Slavery and Abolition, 35(2), 328-48. doi: 10.1080/0144039X.2013.870789

Allen, R.B. (2017). Ending the history of silence: reconstructing European slave trading in the Indian Ocean. Revista Tempo [Brazil], 23(2). doi: 10.1590/TEM-1980542/x2017v230206

Anderson, C. (2000). Convicts in the Indian Ocean: transportation from South Asia to Mauritius, 1815-53. London: Macmillan Press.

Anderson, C. (2007a). The Indian uprising of 1857-8: prisons, prisoners and rebellion. London: Anthem Press.

Anderson, C. (2007b). Sepoys, servants and settlers: convict transportation in the Indian Ocean, 1787-1945. In F. Dikötter \& I. Brown (Eds.), Cultures of confinement: a history of the prison in Africa, Asia and Latin America (pp. 185-220). Ithaca, NY: Cornell University Press. Anderson, C. (2009). Convicts and coolies: rethinking indentured labour in the nineteenth century. Slavery and Abolition, 30(1), 93-109. doi:

10.1080/01440390802673856

Anderson, C. (2012). Subaltern lives: biographies of colonialism in the Indian Ocean world, 1790-1920. Cambridge: Cambridge University Press.

Armstrong, J.C. (2012). The Chinese Exiles. In N. Worden (Ed.). Cape Town between east and west: social identities in a Dutch colonial town (pp. 101-27). Auckland Park, South Africa: Jacana Media. Blackburn, R. (1988). The overthrow of colonial slavery. London: Verso. Bolland, O.N. (1981). Systems of domination after slavery: the control of land and labor in the British West Indies after 1838. Comparative Studies in Society and History, 23(4), 591-619. Retrieved from https://www.jstor.org/stable/178395?seq=1 - page_scan_tab_contents Bowen, H.V. (2006). The business of empire: the East India Company and imperial Britain, 1756-1833. Cambridge: Cambridge University Press. Fisher, M.H. (2004). Counterflows to colonialism: Indian travellers and settlers in Britain, 1600-1857. Delhi: Permanent Black.

Fisher, M.H. (2006). Working across the seas: Indian maritime labourers in India, Britain, and in between, 1600-1857. In R.P. Behal \& M. van der 
Linden (Eds.), Coolies, capital, and colonialism: studies in Indian labour history (pp. 21-45). Cambridge: Cambridge University Press. Forster, C. (2002). Convicts: unwilling migrants from Britain and France. In D. Eltis (Ed.), Coerced and free migration: global perspectives (pp. 259-91). Stanford, CA: Stanford University Press.

Fox, C. (2017). A bitter draught: St. Helena and the abolition of slavery, 1792-1840. Norfolk, UK: Society of Friends of St. Helena.

Geber, J.L. (1998). The East India Company and southern Africa: a guide to the archives of the East India Company and the Board of Control, 1600-1858 (unpublished doctoral dissertation). University of London. Grubb, F. (2000). The transatlantic market for British convict labor. Journal of Economic History, 60(1), 94-122. Retrieved from https://www.jstor.org/stable/2566798?seq=1 page_scan_tab_contents

Harfield, A. (1995). Bencoolen: a history of the honourable East India Company's garrison on the west coast of Sumatra (1685-1825). Barton-on-Sea, UK: A. and J. Partnership.

Jayasuriya, S. (2009). East India Company in Sumatra: cross-cultural interactions. African and Asian Studies, 8, 204-21.

Jones, E. (2010). Wives, slaves, and concubines: a history of the female underclass in Dutch Asia. DeKalb, IL: Northern Illinois University Press.

Knaap, G., \& Sutherland, H. (2004). Monsoon traders: ships, skippers and commodities in eighteenth-century Makassar. Leiden: KITLV Press.

Lockard, C.A. (2013). Chinese migration and settlement in Southeast Asia before 1850: making fields from the sea. History Compass, 11(9), 765-81. Doi: https://doi.org/10.1111/hic3.12079

Logan, F.A. (1956). The British East India Company and African slavery in Benkulen, Sumatra, 1687-1792. Journal of Negro History, 41(4), 33948. Retrieved from https://www.jstor.org/stable/2715359

Major, A. (2012). Slavery, abolitionism and empire in India, 1772-1843.

Liverpool: Liverpool University Press.

McKeown, A. (2004). Global migration, 1846-1940. Journal of World History, 15(2), 155-89. doi: https://www.jstor.org/stable/20068611 
Philips, C.H. (Ed.). (1951). The correspondence of David Scott, director and chairman of the East India Company, relating to Indian affairs, 17871805, vol. 1. London: The Royal Historical Society.

Platt, V.B. (1969). The East India Company and the Madagascar slave trade. William and Mary Quarterly, $3^{\text {rd }}$ ser., 26, 548-77.

Raben, R. (2008). Cities and the slave trade in early-modern Southeast Asia. In P. Boomgaard, D. Kooiman, \& H.S. Nordholt. Linking destinies: trade, towns and kin in Asian history (pp. 119-40). Leiden: KITLV Press.

Rediker, M., Pybus, C., \& Christopher, E. (2007). Introduction. In E. Christopher, C. Pybus \& M. Rediker (Eds.), Many middle passages: forced migration and the making of the modern world (pp. 1-19). Berkeley: University of California Press.

Robins, N. (2006). The corporation that changed the world: how the East India Company shaped the modern multinational. London: Pluto Press.

Sen, S. (2000). Disciplining punishment: colonialism and convict society in the Andaman Islands. New Delhi: Oxford University Press.

Stern, P.J. (2011). The company-state: corporate sovereignty and the early modern foundations of the British empire in India. Cambridge:

Cambridge University Press.

Van Welie, R. (2008). Slave trading and slavery in the Dutch colonial empire: a global comparison. New West Indian Guide/Nieuwe WestIndische Gids, 82(1 \& 2), 47-96. Retrieve from https://www.jstor.org/stable/43390702?seq=1 page_scan_tab_contents

Vink, M. (2003). 'The world's oldest trade.' Dutch slavery and slave trade in the Indian Ocean in the seventeenth century. Journal of World History, 14(2), 131-77. Retrieved from https://www.jstor.org/stable/20079204?seq=1 page_scan_tab_contents

Ward, K. (2009). Networks of empire: forced migration in the Dutch East India Company. Cambridge: Cambridge University Press. 
176 Allen - Slavery in a Remote but Global Place

Winterbottom, A. (2011). From hold to foredeck: slave professions in the maritime world of the East India Company, c. 1660-1720. In M. Fusaro \& A. Polónia (Eds.), Maritime history as global history (pp. 95-124). St. John's, NL: International Maritime Economic History Association.

Wyman-McCarthy, M. (2014). Rethinking empire in India and the Atlantic:

William Cowper, John Newton, and the imperial origins of

evangelical abolitionism. Slavery and Abolition 35(2), 306-27. doi:

https://doi.org/10.1080/0144039X.2013.800277

Yang, A.A. (2003). Indian convict workers in Southeast Asia in the late eighteenth and early nineteenth centuries. Journal of World History, 14(2), 179-208. Retrieved from

https://www.jstor.org/stable/20079205?seq=1 page_scan_tab_contents

Young, R.J. (1989). Slaves, coolies and bondsmen. A study of assisted migration in response to emerging English shipping networks in the Indian Ocean, 1685-1776. Indian Ocean Review, 2(3), 23-26.

Richard B. Allen: Editor of the Indian Ocean Studies Series, Ohio University Press.

Contact Address: rallen1@framingham.edu 